\title{
Religious Gullibility, Health and Wellbeing among Epilepsy Patients in Zimbabwe
}

\author{
Vincent Mabvurira \\ ORCID iD: https://orcid.org/0000-0003-0960-230X
}

\section{Jabulani Calvin Makhubele ORCID iD: https://orcid.org/0000-0002-0192-573X}

\begin{abstract}
With the advent of the new millennium, Zimbabwe has witnessed a mushrooming and a boost in the 'church industry'. Indications are that congregants blindly and sheepishly follow their leaders, despite questionable holiness and relationships with the Most-High God. Religious gullibility seems to have reached unprecedented levels amidst the economic crises and poor state service delivery in Zimbabwe. Religion and spirituality are believed to be sources of strengths and resilience during tough times in human life. They help people to cope with life's adversities. It is against this backdrop that this study sought to explore the health and wellbeing of epileptic members of Christian churches in Zimbabwe. The study adopted an ethnographic design in which data were collected over a period of one year through participant observations and unstrucktured interviews. Purposive and convenience sampling were used to identify churches and participants of the study. The study found that the participants had high commitment to their churches and they expected miraculous healing of their epileptic condition. They all believed that leaders of their churches were sent by God. Various healing methods such as anointing oil/water, tangible material and laying on of hands were used. Generally, their church membership and spirituality provided them with a sense of meaning in their lives.
\end{abstract}

Keywords: spiritual wellbeing, Pentecostal/ism, resilience, spiritual healing, religious gullibility, epilepsy 


\section{Introduction}

Recent days have seen a boost in the emergency and proliferation of Pentecostal and apostolic churches in Zimbabwe. Religious gullibility has taken Zimbabwe by storm. This observation is corroborated by Mandizadza and Chidarikire (2016: 148,) who notes that,

Generally, Zimbabwe is a predominantly Christian country and anecdotally it is apparent that since 2000 there has been an upsurge in Pentecostal activities centred on young charismatic pastors and prophets from spirit-type, African initiated churches.

The new phenomenon of religious outburst, which includes Evangelical, Pentecostal and Charismatic churches, is often referred to as the new face of Africa. Unlike the traditional orthodox churches, the new breed of churches is characterised by prophecy, spiritual healing, miracle working and the gospel of prosperity. Bible stories are selectively used to buttress the message of prosperity.

These modern churches place emphasis on success, emphasising material prosperity. The churches develop confidence and self-pride among worshippers. Despite the controversy around them and their business, many Zimbabweans have flocked to them for various reasons. One explanation might be that Africans are naturally very religious compared to other races (Mbiti 1979). For them religion is life and life is religion. Another explanation may be the inaccessibility of allopathic medicine due to the economic stagnation haunting the country (Mabvurira 2016). Many Zimbabweans with health and related social problems may not be able to afford social services; hence they turn to spiritual healing (Mabvurira, Makhubele \& Shirindi 2015). Africans are a cure-seeking people and consequently illness attracts a spiritual intervention among most of them. Spiritual healing has assumed a centre stage in the lives of many Zimbabweans. Some of the practices and healing methods used in these churches have remained strange and it remains unclear how members and patrons of such churches are deceived to believe anything alleged to be said by the spirit (Mabvurira et al. 2015).

Spiritual healing is also common among members of Apostolic and Zionist churches in Zimbabwe. Mabvurira et al. (2015) studied healing practices at the Johanne Masowee Chishanu Church and found the use of tangible 
objects such as stones, clay pots, tree leaves and cloths. Of late, the use of materials such as anointing oil and wrist bands has become popular in Pentecostal churches. In extreme cases, the prophets use objects or materials that were never used in the Holy Bible which they claim to follow. These prophets are required by law to register with the Traditional Medical Practitioners Council as provided by the Traditional Medical Practitioners Act (Chapter 27: 14), but in most circumstances they have been defiant, as they associate the council with African traditional religion.

Spiritual healing is subjective, dogmatic speculation, based on faith rather than empirical evidence (Newsdze Zimbabwe 12 August 2017). Most people afflicted by diseases classified by medical science as beyond cure turn to God for healing. Mapamhidze (2013) confirms unbelievable incidences of healing at some prayer meetings. People report healing of diseases such as HIV and AIDS, cancer, and healing of natural impairments as well success in their businesses. Prophets seem to offer some certitude in the everyday lives of people haunted by incurable diseases (Chitando 2009).

This qualitative study sought to examine the impact of religious gullibility in Zimbabwe on the health and wellbeing of sufferers of epilepsy. Its specific objectives were to assess the level of religious commitment among epileptic patients, examine factors promoting gullibility among congregants and evaluate the impact of religious gullibility on the health and wellbeing of epileptic patients.

The study was guided by the transpersonal theory. The word 'transpersonal' refers to transcending the limits of the ego (Cheon 2010). In the words of Robbins et al. (2006: 386), transpersonal theories concern our highest aspirations and potentials and our need for love, meaning, creativity and communion with other people. The focus on the experiential and cognitive dimensions of spirituality is one of the main factors that distinguish transpersonal theory from other scientific and humanistic disciplines. Since its inception, transpersonal theory has given spirituality a central place in the understanding of human nature.

\section{Background Information on Epilepsy}

Epilepsy is triggered by abnormal electrical activity in the brain, resulting in an involuntary change in body movement, function, sensation, awareness and behaviour (Centers for Disease Control and Prevention n.d.). The condition is 
characterised by repeated seizures (WHO 2004). Epilepsy affects more than 50 million people globally and more than 10 million people in Africa (WHO 2004). It is a highly stigmatised disease associated with witchcraft, revenge from aggrieved spirits and visitation by the devil (Adamolekun \& Mundanda 1997). Consequently, the management of epilepsy is assumed to be the domain of spiritual healers. Epileptic patients face numerous challenges, which range from expulsion from school, job loss, stigmatisation and discrimination in society. People with epilepsy in Zimbabwe have numerous challenges, including poor understanding of the disease, impaired access to treatment, and a predisposition to burns and injuries. In a study by Mugumbate and Nyanguru (2013: 30), epileptic patients reported numerous challenges, such as psychosocial $(75 \%)$, lifestyle $(91 \%)$, economic $(64 \%)$, physical $(45 \%)$ and health (21\%) challenges.

Apart from being a medical condition, epilepsy also has sociological, economic and cultural dimensions. According to the WHO (2004), secondary causes of symptomatic epilepsy in Africa are related to the cerebral complications of endemic, parasitic and infectious diseases, head trauma and poor perinatal care for both the mother and the child. With modern medicine, epilepsy can be controlled, but not cured. This is probably the major reason people seek spiritual healing where they are promised total cure. Epilepsy in Zimbabwe has attracted several derogatory names: zvipusha (a condition that is infectious), pfari (jerking) and kugwinha (fitting).

People with chronic conditions in Zimbabwe, including epilepsy, have not been spared religious gullibility. Gullibility is a situation where powerful people use some guile to make people believe seamlessly impossible issues/facts (Mutswanga 2017). According to Thomas Reid (cited in Mutswanga 2017), humans have a natural propensity to be trusting, even things they have not seen or touched, and they end up being victims of gullibility. The Bible as a moral teaching tool contains many stories in which the trust of unsuspecting individuals is violated by those who use deception, dishonesty and manipulation (Mutswanga 2017).

\section{Health, Religious and Spiritual Wellbeing}

The spiritual needs of people with chronic conditions are well researched in a number of countries (Moadel et al. 1999; Hampton et al. 2007; Yong et al. 2008; Bussing, Balzat \& Heusser 2010). Many patients who are confronted 
with chronic conditions rely on spirituality and religion to cope (Bussing \& Koenig 2010). Spirituality and religion are beneficial in that these help to maintain self-esteem, providing a sense of meaning and giving emotional comfort. They are also gaining attention in healthcare because they play a vital role in the lives of patients who are recovering from life-threatening illnesses and those who are in palliative or end-of-life care (Bernard et al. 2014).

A number of scholars argue that participation in religious activities is strongly associated with a reduction in mortality (Seyed, Nooshin \& Hassan 2016; Moadel et al. 2010; Cascio 2012). According to UNICEF (2003), churches have strengths; they have credibility, and they are grounded in communities. This offers them opportunities to make a real difference in combating chronic conditions such as HIV and AIDS. A number of people with chronic conditions receive encouragement from their pastoral staff.

According to Vance et al. (2011), spirituality and religion can serve as a buffer to the stress of life by allowing people to interpret their life experiences in the context of their beliefs, which provide purpose and meaning in life. Generally, chronic disease literature shows the benefits of spirituality and religion in buffering one from stressors of such diseases. In a study by Lorenz et al. (2005) among HIV-infected Americans, $80 \%$ of the participants reported that their religion and spirituality were important in their lives. Often, the spirituality of people can increase after being diagnosed with a life-threatening condition (Vance et al. 2011).

The comfort of spirituality reduces the distress of life-threatening illnesses. The study by Peterson, Johnson and Tenzek (2010) among HIVpositive women in the USA, shows that respondents believed God had a purpose for their lives and that connecting spiritually to God as a higher power, provided them with a way to make sense of and make changes to their lives.

\section{Resilience and Religious Coping}

There is a growing interest in recognising spirituality as a source of strength and resilience. In a study of African American women in Kansas in the USA, Banerjee and Pyles (2004) found that the women reported that their spirituality helped them to manage their difficult situations by reassuring them that a higher power is looking after them. The women also argued that spirituality helped to lessen the impact of problems on them, to find inner peace, and to build self-esteem. It also helps to nurture hope, despite the challenges of life. 


\section{Vincent Mabvurira \& Jabulani Calvin Makhubele}

Resilience may result in an individual bouncing back to a previously normal functioning, or not showing any negative effect. According to Martin and Martin (2002), spirituality can give people the strength to go where there is a threat and it also provides courage and encouragement amidst suffering and death. Religion can provide a world-view that helps give purpose and meaning to suffering.

Crawford, Brown and Bonham (2006) note that spirituality facilitates resilience in four major ways: by helping build attachment relationships; by opening access to social support; by guiding conduct and moral values; and by offering opportunities for personal growth and development. Apart from improving resilience, spirituality has also been found to improve selfconfidence and life purpose among youths in stressful situations. Writing in the context of America, Corrigan, McCorkle, Schell and Kidder (2003) argue that research has it that those members of the general population who define themselves as religious and spiritual have less psychological distress, more life satisfaction and greater achievements of life goals.

Several studies have shown that many people cope with traumatic or stressor events on the basis of their religious beliefs. Religious frameworks and practices may have an important influence on how people interpret and cope with traumatic events. People are better able to get through difficult times if they have faith and hope. No one experiences God in the same way. Some people express their faith emotionally, while others do so quietly and contemplatively.

Religion and spirituality are some of the significant means of coping with crises and problems in everyday life. According to Pargament (1997), religious coping involves drawing on religious beliefs and practices to understand and deal with life stressors. Religious coping can be divided into two categories: positive and negative strategies. Rosmarin, Pargament, Krumrei and Flannelly (2009) note that positive religious coping includes benevolent religious approaches, active religious surrender, seeking spiritual support and spiritual connection, while negative strategies include a reappraisal of God's power, passive religious deferral, and interpersonal religious discontentment. They further indicate that positive religious coping is beneficial to individuals undergoing stressful life events. According to Openshaw and Harr (2005), many clients draw support from their faith group, which is useful in that it assists with healing and rebuilding hope. People engulfed by social problems such as ill-health, death and other existential 
challenges have been found to seek refuge in spirituality.

People reflect on their spirituality after being diagnosed with a chronic illness by incorporating their understanding of God as part of their coping repertoire (Tarakeshwar, Khann \& Sikkema 2006). Higher levels of spirituality have been associated with less pain and increased energy (Ramer, Johnson, Chan \& Barret 2006). According to Parsons, Cruise, Davenport and Jones (2006), the negative aspects of spirituality such as spiritual struggle and anger at God have been associated with poor medical compliance. Types of spiritual beliefs and practices determine whether or not spirituality will be a protective or risk factor in the lives of people with chronic illnesses. Cicirelli (2002) concludes that religiousness is negatively associated with fear of death. Healthcare professionals should be able to accommodate spiritual issues in the helping process and where they cannot handle such issues, they can refer clients for clinical and pastoral counselling.

It also assists in alleviating the adverse effects of stress caused by life's challenges. Spiritual concerns such as hope, meaning, inner strength and doubt are relevant in the lives of many clients (Gotterer 2001).

Chronic conditions present exceptional existential challenges to people when they are confronted with issues of hope, death, grief, meaning/purpose, and loss. People with HIV and AIDS incorporate spirituality as a way to cope, to help reframe their lives, and to bring a sense of meaning and purpose to their lives in the face of an often devastating situation. According to Harrington (2010), four claims have been confirmed in relation to religion and health. These are:

(1) church attendance increases longevity and resistance to disease;

(2) Spiritual practices (like meditation) reduce stress and enhance health;

(3) Faith in God can facilitate recovery from serious illness; and

(4) Prayer for another can change the outcome of disease.

\section{Methodology}

This study adopted a qualitative approach. Engel and Schutt (2009) note that data that are treated as qualitative are mostly written or spoken words or observation that do not have a direct numerical interpretation. According to Padgett (2008), qualitative design is the best fit when explaining a topic that 
little is known about, especially from an insider's perspective and where an indepth understanding is sought. Qualitative research is also suitable when one pursues a topic of sensitivity and emotional depth (Padgett 2008). According to Padgett (2008), in qualitative research, the focus is on flexibility and depth, rather than on mathematical probabilities and external validity.

The current study targeted people living with epilepsy who thronged Pentecostal churches in the Harare Metropolitan Province. The sample for the study comprised nine participants (eight females and one male) drawn from three churches. Purposive sampling was used to select churches that were visited while convenience sampling was used to select participants. Data were collected through non formal unstructured interviews and participant observations. The data were gathered between August 2017 and July 2018. Data were analysed using thematic content analysis.

\section{Presentation and Discussion of Results Description of Participants}

Data were collected from nine sufferers of epilepsy. Of these, eight were females while one was male. The participants ranged in age from 15 to 42 years. The average number of years with epilepsy was 19 years. All the participants were not formally employed. Of the eight women, three were young girls below the age of 18 years; four were single mothers; while one was married. The only male participant was single and 33 years old. Five of the participants were under allopathic medication, while four relied solely on spiritual healing. All the churches had Sunday as their main day of worship, though they held midweek services.

\section{Motivation for Church Membership}

The participants were committed members of their respective churches. They reported rarely missing church activities. They reported various reasons as motives for church membership. One respondent reported that she was a member of her church because she was born a Christian and her family attended the same church. Of interest was a participant who reported that her family joined the church because of her illness. Probed further, she reported that: 
We heard testimonies from this church through a television channel and my family was convinced that my condition will be cured ...

On the same note, another participant reported,

... I stay with my auntie and she told me about the miracles that occur in this church so we were convinced to come.

The nine participants all reported that they continued going to their churches because of healing powers. Three participants confirmed that since they had joined their respective churches they were totally healed. They confirmed this verbatim as follows,

I was healed in this church so I love it, I can't leave it.

My prophet told me that if I backslide the devil will take advantage and the illness will resurface.

I come here because that's where I received my miracle ...

The male participant reiterated that:

The God of this church is so great, I would fit, become unconscious and urinate, it was so embarrassing especially in the public but since I started using holy water from this church everything is now okay.

Three participants reported getting material support from the churches. The material support came in the form of food items, clothes, blankets and money. As seen in this study, people join Pentecostal churches for various reasons, chief among them the expectation of good things like healing. In these modernday charismatic churches, people are promised total healing. Whether they actually receive the healing or not is debatable. Results of the study have shown that both those who have been healed and those expected to be healed remain loyal to their churches. A gospel of hope, healing and wealth is preached, such that members continue in expectation. In some instances, other congregants are alleged to connive with pastors to pretend to be sick and to have been healed. This makes fellow congregants believe that healing takes place in the church 
when actually there is none. In modern-day Zimbabwe, it is common for pastors to advertise their healing services on television and radio stations, internet platforms and through pastors. This may draw people in need of help to their churches. Relatives play a critical role in influencing the gullibility of Christians in Zimbabwe. As shown by this study it is possible for an entire family to join a particular church in expectation of a member's healing.

\section{Healing Methods}

Some of the modern-day Pentecostal churches use astonishing healing methods. Cases of congregants asked to drink jik detergent have been reported in Zambia (Ndlovu 2019). An extreme case in Zimbabwe was when congregants were reported to have been asked to drink raw sewage as a way of demonstrating the power in their prophet by not falling sick (Charamba 2016). The participants reported using various healing methods:

\section{Anointing Oil and Water}

All the participants reported using either anointing oil and/or anointing water. This is bottled anointing oil/water sold to congregants. It is usually packaged in small bottles smaller than $100 \mathrm{ml}$. Quite often the church founders renew the anointing oil/water to more powerful levels. The researchers observed differences in bottle shape and labels on the containers as the anointing oil/water was improved. Whether it is a mere change of container remains unknown to ordinary people. Participants were very convinced that new oil/water was always more powerful than the previous one. One participant had to say,

Apostle told us that the new oil is so powerful. He spent many days in the prayer mountain praying for it. I tell you with it my condition will disappear ...

The oil or water was used in various forms. The pastors would spray it on congregants for healing purposes or driving away demons. The congregants would also buy it and use it in their homes for protective reasons. One participant reported using it daily in the morning as a face lotion. She reported that it has the power to deter demons and other evil things. 
The use of anointing oil or water has become popular in Zimbabwe. Anointing oil is used by prominent prophets like Walter Magaya of Zimbabwe, while anointing water is used by renowned church leaders like T.B Joshua of Nigeria (Mabvurira 2016). Emerging prophets in Zimbabwe have adopted the use of anointing oil/water. As seen by the results of this study, congregants are very confident that they may be healed by the oil/water. There are even testimonies of healing from the oil and/or water. However, spiritual healing is difficult to prove, as there are allegations of people who fake illness and healing. As supported by Newsdze Zimbabwe (2017), it is dogmatic and based on speculation rather than on empirical evidence.

\section{Healing and Prophesy Sessions}

All three the churches from which participants were drawn conducted healing sessions. These sessions usually occurred at the end of Sunday services or whenever the prophet claimed to have been instructed by the Spirit to do so. During such sessions, the prophet would either call sick people to come for healing or would just pick a person from the crowd and administer healing. In some cases, the prophet would ask other ordained church leaders to help with praying for the sick. The researchers observed that healing sessions rarely occurred in the absence of the church founder. Healing and prophecy were observed to be centred around particular individuals. A 42-year-old participant reported that at her church, only the prophet and his wife were authorized to conduct healing or prophesy. Asked why this was the situation she reported,

The prophet told us that a student cannot be above his teacher, if my student feels he is now a teacher, he is free to start his own ministry.

Healing was also administered through the laying of hands by the prophet or other senior church members. All the participants reported that they preferred being prayed for by the prophet rather than by any other person. Having personal contact with the prophet therefore meant a lot for the congregants. This was confirmed by one participant who said,

... I have been in this church for the past three years and the man of God has never laid his hand on me nor has he prophesied about me. I 
long to have him lay his hands on me but the opportunity has not arisen. I am confident that one day he will pick me from the crowd ....

It was also corroborated by another participant who said,

Our church is so large that talking to Papa is a blessing in itself. The day he picks you from the crowd you will know that the floodgates of heaven have opened for you. We all desire such an opportunity.

It was also common for church leaders and elders to pray for various problems that haunted congregants. These problems included poverty, unemployment, homelessness and sickness. The praying person would make strong proclamations and congregants would be heard shouting 'Amen', 'Hallelujah', 'Prophesy Papa', and many other words. After the prayer, people would usually clap hands, thanking God for meeting them at their point of need. At one church service attended by the researchers, the prophet ordered people to shout the following words after his prayer,

I am rich, I am not poor, I am healed, I am not sick, I am a landlord, I am not a tenant, I drive, I am not a pedestrian ....

The congregants would joyously repeat these words, ululating, clapping hands and whistling. There was joy whenever a preacher or someone praying mentioned something to do with prosperity. This seemed to energize the congregants and instil positive thinking among them.

Africans are generally a cure-seeking people (Mabvurira 2016). For them, diseases do not just occur without a spiritual causation. This is one reason why they seek the help of a spiritual body whenever illness confronts them. The nine epileptic patients in this study were all found to value healing and prophecy. In a similar observation, Chitando (2009) argues that prophets seem to offer some certitude in the lives of people affected by incurable diseases. Epilepsy in Zimbabwe is marred by myths and misconceptions; hence, people have faith in spiritual healing. The gullibility of the participants can also be supported by Bussing and Koenig (2010), who found that many patients with chronic conditions use religious and spiritual coping mechanisms. 


\section{Demon of Exorcism}

Among most Africans, spiritual forces are still considered to be the obstacle to success. Closely linked to healing was exorcism of demons. This is a situation whereby an anointed person drives out a demon/evil spirit believed to be causing problems in one's life. All the participants believed that epilepsy was caused by evil spirits. Exorcism was confirmed by the following statements from the respondents,

Whenever I am prayed for, I collapse and people tell me that I manifest a spirit of a snake ....

I have a demon tormenting me, I was captured by a church camera rolling on the ground saying things that I don't even know. I am so embarrassed that people have that video clip but the good thing is that my situation is improving.

Here we have a holy circle where we chase away demons, they manifest and we instruct them to go. That is why this place is always busy, people throng it for healing and cleansing of various troubles ....

There is a God in this place, demons just manifest even during praise and worship time ....

I manifest a demon saying I will not achieve anything in life hence this epilepsy ....

Mabvurira (2016) found that most Shona people in Zimbabwe believed in demons as being responsible for mishaps in their lives. The same was found in the current study where a number of the participants believed that the evil spirit was responsible for their illnesses. As such, they valued demon exorcism. Exorcism of demons provides a clear avenue for the healing process where people see an evil spirit manifesting and going away. Modern-day pastors take advantage of this attribute in most Zimbabweans and they do all they can to prove that somebody is possessed by a spirit and that they can drive away the spirit. In a related study, Mabvurira et al. (2015) found that exorcism among sick members of the Johanne Masowe Chishanu Church gave congregants confidence that their situations may be corrected. This is so 
because most Zimbabweans have the propensity to love miracles.

\section{Church Material}

Almost all the participants (eight) reported wearing or possessing churchbranded and anointed materials. The materials ranged from church flags, tshirts, wristbands, pens, etc. They were either branded with the church logo, or the church's name or the pastor's name in writing. All the participants believed that these had a protective factor. They all reported buying the materials from the church. The use of church material was confirmed by the following,

I will wear this wrist band until Papa tells me to remove it ....

The church logo on my t-shirt make demons flee and I feel protected whenever I put on this t-shirt ....

I have a church calendar in my house with my spiritual father's picture $\ldots$. and that is my anchor of protection ....

The participants were observed wearing wristbands and t-shirts, especially during church services.

The use of tangible material has been present since Biblical times and in traditional African healing ceremonies. However, as seen by the results of the current study, the participants reported that prophets now use sophisticated items like their pictures for healing purposes. It is not clear whether the prophet's picture represents God or not. It may be deduced that prophets may instil a sense of fear in congregants and allege that they have solutions to the people's problems. This may explain why congregants have so much faith in church materials for their success in life. Whether it is God or the prophet who does the healing is now questionable. There are even rumours that some of the prophets get powers from traditional healers.

\section{Genuineness of Church Founder and Church Activities}

Asked whether their pastor/prophet was genuine and called by God, all the participants reported that they believed their prophet was a Man of God. This 
is attested by the following statements,

This is a prophet of God ... You hear newspaper people writing bad things about him, they should be careful as they may be fighting God himself.

He is called, I do not doubt anything about him and his wife ...

Surely there is a prophet in our land, that's why you see people coming from all over the places to meet him ...'

Eight of the participants reported that they did anything that the Pastor prescribed without asking questions. This was done in the name of faith, as shown by the quotes below,

You don't have to doubt God or a Man of God, just believe and everything else will be sorted ...

If the spirit says do this I have to do it, I can't challenge God ...

The children of Israel spend many years in the wilderness because of doubting the man of God Moses ...

Whether the modern-day prophets in Zimbabwe are genuine and sent by God is the biggest question of the moment. Gullible congregants believe they are, whilst non-gullible people believe they are not. The challenge is to disprove that they are not. Those who have tried to disprove them have been referring to the Bible, while the prophets also make reference to the same Bible when supporting their deeds. According to John 14:12 (KJV), 'Verily, verily, I say unto you, He that believeth on me, the works that I do shall he do also; and greater works than these shall he do ...' (KJV). Hence the prophets argue that they are doing the greater work promised by Jesus.

\section{Music}

Music was found to play a critical role in the lives of people with epilepsy. At all the churches that participated in the study, there were generally music 


\section{Vincent Mabvurira \& Jabulani Calvin Makhubele}

sessions, and praise and worship music. Praise was done to applause and thank God and worship songs were sung to connect the congregants with the Holy Spirit. Praise songs are associated with high pitch, dancing and playing music instruments, while worship songs have a low pitch and trigger a sense of divine connection with the Supreme Being. It was worship songs that triggered emotions among congregants. Some participants were seen shedding tears during worship time. Some would raise their hands shouting words like 'Come down, Holy Spirit', while others would kneel down clapping their hands. Some participants confirmed that some songs had bearing on their lives as epilepsy patients. This was confirmed by the following statements,

There are certain songs which if sung I feel connected with my God.

Whenever I am weak I sing the song Jehovah my healer ...

There are songs that really touch me and I feel energized and worthy despite people looking down upon me because of my illness.

Music plays a stupendous role in most religions across the globe. It is one way in which worshippers express their spirituality. In the current study it was found to be critical, as it gave congregants an avenue to connect with their Supreme Being. Particular songs were found to promote positive thinking among epileptic patients. Music promoted resilience of congregants.

\section{Vigils}

All the churches conducted vigils from time to time. Frequencies varied from quarterly to weekly. One of the churches had all-night prayers every Friday. Seven of the participants confirmed that they would not miss an all-night prayer without a valid excuse. The vigils were seen as an opportunity to spend time with God. Probed further, the participants confirmed that they used the vigils to communicate their problems to God, as well as to thank him for prayers answered. All the participants reported that they always prayed for their health, apart from other needs, as well as those of their relatives. In extreme circumstances, congregants would spend the whole night on a prayer mountain during cold nights. One participant reported that she fell ill after spending several Friday nights at prayer sessions in the mountain. She 
indicated that their prophet had told them that God would not forsake those who chased after His face.

Participation in religious activities has been found to be important in the lives of people with chronic illnesses. When people spend the whole night at a church services, they feel they had enough time to communicate with the Supreme Being. These night vigils are present even in other religions like African indigenous religions and Islam.

\section{Sermons}

Preaching of the Word played an important function in the lives of epileptic patients. In the churches visited the Bible was selectively used to justify the prophets' actions. A classic example was John 5:1-15 (KJV). It talks of a man who was healed after 37 years at the Pool of Bethesda. This verse was interpreted by a preacher to mean that it may take long, but one day the congregants would meet Jesus Christ and be healed. Various sermons were preached to convey various messages to the congregants. However, there was a bias towards messages to do with healing and acquisition of material things. Rarely were messages of Salvation preached. The male participant would take turns to stand behind his prophet as he preached. Asked why it was necessary he indicated that it was the rule of the church that an 'Armour Bearer' stands behind the 'Man of God' during sermons. This was found to promote resilience in the participant. He believed that as long as he served in the Lord's house, the Lord was not going to forsake him.

Sermons were the main strategy used by prophets to instil patriotism among their congregants. They were twisted to motivate weary people in difficult circumstances. Almost every situation that a congregant found $\mathrm{him} /$ herself in was interpreted used the Bible. Quite often the epileptic patients were told that their sickness came so that the name of the Lord be glorified (John 9: 1-12 KJV).

\section{Conclusion}

Zimbabwe has not been spared from religious gullibility. Gullibility has been found to play an important role in the lives of people with epilepsy. Epileptic patients in Zimbabwe find comfort in religion. Some people participate in religious activities with the hope of getting healed while some claim they have 
been healed. They use various religious materials to get protection as most of them claim that epilepsy is caused by evil spirits. Though viewed negatively by some, religious gullibility serves a purpose in promoting resilience and is used as a coping mechanism by people confronted with chronic conditions like epilepsy.

\section{References}

Adamolekun, M.J. \& B.D. Mundanda 1997. Knowledge and Attitudes of Teachers towards Epilepsy in Zimbabwe. ActaNeurolScandinavica 96: 133-137. https://doi.org/10.1111/j.1600-0404.1997.tb00254.x

Banerjee, M.M. \& L. Pyles 2004. Spirituality, a Source of Resilience for African American Women in the Era of Welfare Reform. Journal of Ethnic and Cultural Diversity in Social Work 13,2: 45-70.

https://doi.org/10.1300/J051v13n02_03

Bernard, W.T., B.N. Maddalena, M. Njiwaji \& D.M. Darrell 2014. The Role of Spirituality at the End of Life in Nova Scotia's Black Community. Journal of Religion and Spirituality in Social Work: Social Thought 33,34: 353-376. https://doi.org/10.1080/15426432.2014.930622

Bussing, A., H-J. Balzat \& P. Heusser 2010. Spiritual Needs of Patients with

Chronic Pain Diseases and Cancer-validation of the Spiritual Needs Questionnaire. European Journal of Medical Research 15,6: 266-273. https://doi.org/10.1186/2047-783X-15-6-266

Cascio, T. 2012. Understanding Spirituality as a Family Strength. Family in Society Newsletter. Families in Society 82,1: 35-48.

Centres for Disease Control and Prevention n.d. Epilepsy and Seizures. Available at:

https://www.cdc.gov/healthcommunication/toolstemplates/entertainment ed/tips/Epilepsy.html (Accessed on 12 February 2019.)

Charamba, M. 2012. Pastor Offers Congregants Raw Sewage as Drinks. Available at: https://bulawayo24.com/index-id-news-sc-national-byo100653.html (Accessed on 14/02/19).

Cheon, J.W. 2010. A Transpersonal Understanding of Youth Spirituality: Implications for an Expanded View of Social Work. Currents: New Scholarship in Human Services 9,1: 1-18.

Chitando, E. 2009. Deliverance and Sanctified Passports: Prophetic Activities 
amidst Uncertainty in Harare. In Haram, L. \& C.B. Yamba (eds.): Dealing with Uncertainty in Contemporary African Lives. Uppsala, Sweden: NordiskaAfrikainsitutet.

Cicirelli, V.G. 2002. Fear of Death in Older Adults: Predictions for Terror Management Theory. Journal of Gerontology: Psychological Sciences 57B,4: 358-366. https://doi.org/10.1093/geronb/57.4.P358

Corrigan, P., B. McCorkle, B. Schell \& K. Kidder 2003. Religion and Spirituality in the Lives of People with Serious Mental Illness. Community Mental Health Journal 39,6: 487-499.

https://doi.org/10.1023/B:COMH.0000003010.44413.37

Crawford, P., B. Brown \& P. Bonham 2006. Communication in Clinical Settings. Cheltenham: Nelson Thornes.

Engel, R.J. \& R.K. Scutt 2009. Fundamentals of Social Work Research. Thousand Oaks: Sage Publications.

Gotterer, R. 2001. The Spiritual Dimension in Clinical Social Work Practice. Journal of Scientific Study of Religion 36: 549-564.

Government of Zimbabwe 1981. Traditional Medical Practitioners Act (Chapter 27: 14). Harare: Government Printers.

Hampton, D.M., D.E. Hollis, D.A. Lloyd, J. Taylor \& S.C. McMillan 2007. Spiritual Needs of Patients with Advanced Cancer. A Journal of Hospital Palliative Care 24: 42-48.

https://doi.org/10.1177/1049909106295773

Harrington, A. 2010. God and Health: What More is There to Say? In Harper

Jr., C.L. (ed.): Spiritual Information: 100 Perspectives on Science and Religion. West Conshohocken: Templeton Foundation Press.

King James Bible 2017. King James Bible Online.

https://www.kingjamesbibleonline.org/ (Accessed on 15 June 2019.)

Lorenz, K.A., R.D. Hays, M.F. Shapiro, P.D. Cleary, S.M. Asch \& N.S. Wenger. 2005. Religiousness and Spirituality among HIV Infected Americans. Journal of Palliative Medicine 8,4: 774-781.

https://doi.org/10.1089/jpm.2005.8.774

Mabvurira, V. 2016. Influence of African Traditional Religion and Spirituality in Understanding Chronic Illnesses and its Implications for Social Work Practice: A Case of Chiweshe Communal Lands in Zimbabwe. Unpublished doctoral Thesis submitted to the University of Limpopo.

Mabvurira, V., J.C. Makhubele \& L. Shirindi 2015. Healing Practices in Johane Masowe Chishanu Church: Toward Afrocentric Social Work with 
African Initiated Church Communities. Studies on Ethno-medicine 9,3:

425-434. https://doi.org/10.1080/09735070.2015.11905461

Mandizadza, E.J.R. \& S. Chidarikire 2016. A Phenomenological Study into the

Role of Spirituality and Religiousness in the Mental Health of People with

Cancer in Zimbabwe. Journal of Spirituality in Mental Health 18,2: 14-

161. https://doi.org/10.1080/19349637.2015.1100972

Mapamhidze, R. 2013. Miracle Healing, Is it Real? Available at:

https://www.newsday.co.zw/2013/07/miracle-healing-is-it-real/

(Accessed on 10 February 2019.)

Martin, E.P. \& J. Martin 2002. Spirituality and the Black Helping Tradition in

Social Work. USA: NASW Press.

Moadel, A., C. Morgan, A. Fotone, J. Grennan, J. Carter, G. Laruffa, A.

Skummy \& J. Dutcher 1999. Seeking Meaning and Hope: Self-reported

Spiritual and Existential Needs among an Ethnically Diverse Patient

Population. Psycho-oncology 8: 378-385.

https://doi.org/10.1002/(SICI)1099-1611(199909/10)8:5<378::AID-

PON406>3.0.CO;2-A

Mugumbate, J. \& A. Nyanguru 2013. Measuring the Challenges of People with Epilepsy in Harare, Zimbabwe. Neurology Asia 18,1: 29-33.

Mutsvanga, P. 2017. Effects of Religion and Traditional African Culture on Gullibility towards People who are Deaf's Marriage Rights: A Case of Harare, Zimbabwe. Journal of Philosophy, Culture and Religion 27: 1322.

Newsdze Zimbabwe 2017. Miracle Prophets Face Ban. 12 August. Available at: http://www.newsdzezimbabwe.co.uk/2017/08/miracle-prophets-faceban.html (Accessed on 17 February 2019.)

Ndlovu, M. 2019. 27 Dead; 18 Hospitalised after Pastor Makes them Drink Jik in Church. Available at: https://bulawayo24.com/index-id-news-scnational-byo-161508.html (Accessed on 16 January 2020.)

Openshaw, L. \& C. Harr 2005. Ethical Issues in the Spiritual. Paper presented at North American Association of Christians in Social Work, Grand Rapids, Michigan. Available at:

https://www.nacsw.org/Publications/Proceedings2005/OpenshawHarrEt

hicsSpiritual\%20Assessment.pdf (Accessed on 19 March 2019.)

Padgett, D.K. 2008. Qualitative Methods in Social Work Research. Los Angeles: Sage publications.

Pargament, K.I. 1997. The Psychology of Religion and Coping: Theory, 
Research and Practice. New York: Guilford Press.

Parsons, S.K., P.L. Cruise, W.W. Davenport \& V. Jones 2006. Religious Beliefs, Practices and Treatment Adherence among Individuals with HIV in the Southern United States. AIDS Patient Care and STDs 20: 97-111. https://doi.org/10.1089/apc.2006.20.97

Peterson, J.L., M.A. Johnson \& K.E. Tenzek 2010. Spirituality as a Life Line:

Women Living with HIV/AIDS and the Role of Spirituality in their Support System. Journal of Interdisciplinary Feminist Thought 4,1. Available at: http://digitalcommons.salve.edu/jift/vol4/iss1/3 (Accessed on 28 August 2018.)

Ramer, L., D. Johnson, L. Chan \& M.T. Barrett 2006. The Effect of HIV/AIDS Progression on Spirituality and Self-transcendence in a Multicultural Population. Journal of Transcultural Nursing 17: 280-289.

https://doi.org/10.1177/1043659606288373

Robbins, S.P., P. Chatterjee \& E.R. Canda 2006. Contemporary Human Behaviour Theory: A Critical Perspective in Social Work. Boston: Pearson Education.

Rosmarin, D.H., K.I. Pargament, E.J. Krumrei \& K.J. Flannelly 2009. Religious Coping among Jews: Development and Initial Validation of the JCOPE. Journal of Clinical Psychology 65,7: 670-683.

https://doi.org/10.1002/jclp.20574

Seyed, Z.B., Z. Nooshin \& J. Hassan 2016. The Impact of Spirituality on Health. Shiraz E-Med Journal 17,6: e39053. Available at:

http://emedicalj.com/en/articles/20465.html

(Accessed on 19 March 2018.)

https://doi.org/10.17795/semj39053

Tarakeshwar, N., N. Khan \& K.J. Sikkema. 2006. A Relationship Based Framework of Spirituality for Individuals with HIV. AIDS and Behaviour 10: 59-70. https://doi.org/10.1007/s10461-005-9052-8

UNICEF 2003. What Religious Leaders can do about HIV/AIDS Action for Children and Young People. New York: UNICEF.

Vance, D.E., M. Brennan, C. Enah, G.L. Smith \& J. Kaur 2011. Religion, Spirituality and Older Adults with HIV: Critical Personal and Social Resources for an Aging Epidemic. Clinical Interventions in Aging 6: 101109. https://doi.org/10.2147/CIA.S16349

WHO 2004. Epilepsy in the WHO African Region: Bridging the Gap. Congo Brazzaville: WHO Regional Office for Africa. 
Yong, J., J. Kim, S.S. Han \& C.M. Puchalski 2008. Development and Validation of a Scale Assessing Spiritual Needs for Korean Patients with Cancer. Journal of Palliative Care 2008,24: 240-246. https://doi.org/10.1177/082585970802400403

Prof. Vincent Mabvurira Department of Social Work School of Psychosocial Health Lifestyle Diseases Research Entity North-West University vinmabvurira@gmail.com

Prof. Jabulani Calvin Makhubele Department of Social Work University of Limpopo Jabulani.Makhubele@ul.ac.za 